\title{
MONITORING PENGGUNAAN KONTRASEPSI PIL KB ORAL DENGAN KEJADIAN HIPERTENSI : LITERATURE REVIEW
}

\author{
Putri, Devy Septya ${ }^{1)}$ Aditya, Martanty ${ }^{2)}$ Hendra, Godeliva Adriani ${ }^{3)}$ \\ Program Studi Farmasi Universitas Ma Chung \\ Email: 611810067@student.machung.ac.id ${ }^{1)}$, martanty.aditya@machung.ac.id ${ }^{2)}$, \\ godeliva.adriani@machung.ac.id ${ }^{3)}$
}

\begin{abstract}
Abstrak
Pil KB oral merupakan salah satu alat kontrasepsi paling banyak digunakan oleh para wanita untuk mencegah kehamilan. Namun pil KB juga memiliki efek samping yang dapat meningkatkan tekanan darah $\geq 140 \mathrm{mmHg}$ (sistolik) dan $\geq 90 \mathrm{mmHg}$ (diastolik) atau dikenal dengan hipertensi. Penelitian ini bertujuan untuk mengetahui apakah penggunaan kontrasepsi pil KB oral dapat menimbulkan resiko terjadinya hipertensi. Metode yang digunakan dalam penelitian ini adalah literture review dengan sumber data melalui pencarian secara menyeluruh dengan mesin pencari PubMed dan Google Scholar untuk menemukan artikel sesuai kriteria inklusi dan ekslusi dengan kata kunci tertentu dalam periode 2010-2020 kemudian dilakukan review. Hasil penelusuran yang didapatkan yaitu 3 artikel ilmiah secara observasional dengan menggunakan metode cohort dan cross sectional. Hasil dari literature review ini menunjukkan bahwa penggunaan kontrasepsi pil KB oral dapat menimbulkan risiko terjadinya hipertensi. Hal tersebut dibuktikan dari artikel ilmiah yang memiliki nilai $p$-value dibawah 0,05 . Namun adapula yang membuktikan bahwa penggunaan kontrasepsi oral di usia muda tidak menyebabkan hipertensi pascamenopause serta terdapat artikel yang menyatakan bahwa tidak ada hubungan yang signifikan antara penggunaan pil KB kombinasi yang didapatkan dari klinik AS dengan penggunaan pil KB kombinasi yang didapatkan tanpa resep dokter tapi penggunaan pil KB perlu lebih di pantau agar tidak terjadi resiko yang diinginkan.
\end{abstract}

Kata Kunci : Hipertensi, literature review, pil KB

\section{Abstract}

Oral contraceptive pills are one of the most widely used contraceptives for women to prevent pregnancy. However, oral contraceptive pills also have side effects, one of which is increasing blood pressure to $\geq 140 \mathrm{mmHg}$ (systolic) and $\geq 90$ $\mathrm{mmHg}$ (diastolic) or known as hypertension. This study aimed to determine whether the use of oral contraceptive pills poses a risk of developing hypertension. The method used in this study was literature review whose data were sourced from thorough searches with the PubMed and Google Scholar to find articles according to the inclusion and exclusion criteria with certain keywords in the 20102020 and then reviewed. The results obtained were 7 scientific articles observed using a case control and cross sectional methods. The results of this literature review indicate that the use of oral contraceptive pills can increase the risk of developing hypertension. This is evidenced by scientific articles with a p-value below 0.05. However, there is also evidence that the use of oral contraceptives at a young age does not cause postmenopausal hypertension and there is an article stating that there is no significant link between the use of combination birth control pills obtained from U.S. clinics and the use of combination birth control pills obtained without a doctor's prescription but the use of birth control pills needs to be monitored more so that there is no desired risk.

Keywords: Hypertension, literature review, oral contraceptive pills

\section{Pendahuluan}

Pertumbuhan penduduk di Indonesia yang setiap tahunnya semakin meningkat sekitar 4,5 juta jiwa merupakan suatu masalah yang sangat menghawatirkan bagi pemerintah karena pemerintah harus lebih bekerja keras dalam rangka menekan laju pertumbuhan penduduk untuk meningkatkan kesejahteraan masyarakat (Setiawati, Handayani and Kuswardinah, 2017). Tingkat pertumbuhan seperti ini dipengaruhi oleh 3 faktor utama yaitu kelahiran, kematian dan perpindahan penduduk. Untuk menekan laju pertumbuhan penduduk melalui faktor kelahiran, pemerintah Indonesia menerapkan program Keluarga Berencana (KB) Nasional. Cara yang akan dilakukan untuk mencegah kejadian tersebut adalah dengan menggunakan alat Pil KB oral kombinasi adalah suatu pil yang mengandung hormon estrogen dan progesteron. Hormon yang terkandung di dalam pil $\mathrm{KB}$ oral dapat berpengaruh pada tekanan darah serta dapat menyebabkan hipertensi. Keberadaan estrogen dapat meningkatkan kadar angiotensinogen yang berperan dalam ReninAngiotensinAldosteron- System (RAAS). Angiotensinogen diubah menjadi angiotensin I oleh renin yang dilepaskan ginjal, kemudian diubah menjadi angiotensin II oleh angiotensin I convertyng enzyme (ACE) yang berperan untuk meningkatkan aliran darah. Saat renin merangsang pembentukan angiotensin II, kelenjar adrenal di dekat ginjal akan ikut terstimulasi untuk menghasilkan hormon aldosteron. Aldosteron ini nantinya akan membuat ginjal lebih banyak menyaring air, elektrolit, serta garam di dalam darah. Hal ini kemudian membuat jumlah cairan dan elektrolit di dalam tubuh bertambah, sehingga tekanan darah pun meningkat. (Susanti et al., 2018).

Berdasarkan profil kesehatan tahun 20152017 hipertensi merupakan suatu penyakit nomor 3 yang masuk dalam sepuluh besar penyakit terbanyak di Kota Malang (DinKes, 2017). Hipertensi adalah suatu keadaan dimana tekanan darah seseorang mencapai $\geq 140 \mathrm{mmHg}$ (tekanan sistolik) dan $\geq 90 \mathrm{mmHg}$ (diastolik) (Kuito dkk, 2019). Hipertensi merupakan suatu penyakit yang dapat semakin berkembang dan dapat merusak organ yang bermakna dalam tubuh sehingga menyebabkan komplikasi pada penyakit lain seperti stroke, infark miokardium, serangan jantung, gagal ginjal bahkan kematian (Kurniawati, 2010).

Sampai saat ini, beberapa penelitian telah menunjukkan bahwa paparan kontrasepsi pil KB oral memiliki efek pada tekanan darah. Namun temuan dari studi epidemiologi asosiasi antara kontrasepsi pil KB oral dan hipertensi masih belum konsisten (Park and Kim, 2013). Berdasarkan uraian 
tersebut, peneliti ingin melakukan telaah literature review melalui jurnal/artikel ilmiah. Literature review merupakan suatu kegiatan membaca, menelaah, menganalisis, suatu bacaan/artikel untuk memperoleh ide-ide, penjelasan, datadata pendukung yang mendukung pokok pikiran utama, serta memberikan komentar terhadap isi bacaan secara keseluruhan dari sudut pandang kepentingan penelitian (Parmin, 2014).

Penelitian yang ditelaah dalam artikel ini menggunakan metode cross sectional study dan cohort, namun didalamnya tetap menggunakan tema yang sama yaitu mengenai monitoring penggunaan kontrasepsi pil $\mathrm{KB}$ oral dengan kejadian hipertensi.

\section{Rumusan Masalah}

Berdasarkan uraian latar belakang diatas maka dapat dirumuskan, apakah penggunaan kontrasepsi pil KB oral dapat menimbulkan resiko terjadinya hipertensi? Tinjauan Pustaka

Kontasepsi berawal dari kata "kontra" yang berarti melawan atau mencegah, sedangkan "konsepsi" merupakan suatu pertemuan antara sel telur yang matang dan sel sperma yang mengakibatkan kehamilan. Sehingga kontrasepsi dapat diartikan sebagai suatu pencegah terjadinya kehamilan akibat pertemuan antara sel telur dan sel sperma tersebut (BKKBN, 2012).

Kontrasepsi juga merupakan salah satu upaya yang dilakukan oleh pemerintah untuk Program keluarga berencana. Program tersebut dilakukan untuk mengatur jumlah anak, jarak dan usia ideal melahirkan, serta mengatur kehamilan melalui promosi perlindungan serta bantuan yang sesuai dengan hak reproduksi untuk mewujudkan keluarga yang berkualitas.

Terdapat beberapa jenis alat kontrasepsi dan metode kontrasepsi untuk mencegah kehamilan. Pemilihan alat kontrasepsi harus disesuaikan dengan kebutuhan pasangan, salah satunya kontrasepsi hormonal. Alat ini umumnya mengandung kombinasi estrogen dan progesteron atau hanya mengandung hormon progesteron. Kontrasepsi pil KB oral dikenal lebih banyak digunakan oleh keluarga berencana dengan alasan alat kontrasepsi tersebut paling efektif, aman, reversibel serta mudah dalam penggunaan (Farida, 2017).

Patofisiologi dari terjadinya hipertensi melalui angiotensin II yang terbentuk dari angiotensin I oleh angiotensin I convertyng enzyme (ACE) yang memegang peran fisiologis penting dalam mengendalikan tekanan darah. Angiotensinogen yang di produksi oleh hati terkandung dalam darah manusia yang selanjutnya akan diubah menjadi angiotensin I oleh renin. ACE yang terdapat pada paru-paru mengubah angiotensin I menjadi angiotensin II.

Renin kemudian disintesis dan disimpan dalam bentuk inaktik yang disebut prorenin dalam sel-sel jukstaglomerular (sel JG). Sel JG merupakan sel-sel otot polos yang dimodifikasi dan terletak pada dinding arteriol aferen tepat di proksimal glomeruli. Apabila tekanan darah menurun atau arteri menurun, akan terjadi reaksi intristik dalam ginjal dan menyebabkan molekul protein dalam sel JG terurai dan melepaskan renin.

Angiotensin II juga sangat mempengaruhi sirkulasi arteri. Angiotensin II merupakan vasokonstriktor yang sangat kuat dan memiliki dua pengaruh utama dalam meningkatkan arteri. Pengaruh pertama yaitu, vasokontriksi timbul dengan cepat. Vasokontriksi sedikit lemah pada vena dan terjadi terutama pada artriol. Pengaruh kedua yaitu, angiotensin II meningkatkan tekanan arteri dengan bekerja pada ginjal untuk menurunkan eksresi air dan garam.

Antidiuretic hormone (ADH) atau vasopresin, dapat disebut dengan bahan vasokonstriktor yang bekerja paling kuat dari dalam tubuh karena bekerja lebih kuat dibandingkan dengan angiotensin. Vasopresin dibentuk di hipotalamus dan diangkut menutuni pusat akson ke glandula hipose posterior, yang akhirnya diseksresi kedalam darah. Aldosteron adalah suatu regulator + penting bagi reabsorbsi natrium $(\mathrm{Na})$ dan sekresi + kalium $(\mathrm{K})$ oleh tubulus ginjal yang di eksresi oleh sel-sel zona glomerulosa pada korteks adrenal. Aldosteron bekerja pada sel-sel prinsipal ditubulus koligentes kortikalis dengan meningkatkan reabsorbsi natrium sementara pada saat yang sama saat meningkatkan sekresi kalium dengan cara merangsang pompa natriumkalium ATPase pada sisi basolateral dari membran tubulus kolingentes kortikalis. Permeabilitas natrium juga dapat ditingkatkan pada sisi luminal membran oleh aldosteron (Sylvestris, 2014). Mekanisme Pil KB Menyebabkan Hipertensi

Status estrogen dan progesteron menyebabkan tekanan darah yang dihubungkan dengan hipertrofi jantung dan peningkatan respon presor angiotensin II dengan melibatkan jalur ReninAngiotensin System (RAS) (Handayani S. D,2010).

Akibat terganggunya system Renin AngiotensinAldosteron mengakibatkan aktivasi abnormal dari RAS yang berperan penting dalam perkembangan dan perbaikan hipertensi. Angiotensin II sebagai faktor pemicu yang mempengaruhi sistem renin angiotensin dapat meningkatkan tekanan darah, aktifitas sistem nervus simpatetik, pelepasan aldosteron, retensi air dan hipertrofi jantung (Sudayasa, 2017). Kadar estrogen yang tinggi dalam tubuh memicu angiotensinogen untuk beraktifasi sehingga angiotensinogen yang dibantu oleh renin berubah menjadi angiotensin I. Sifat angiotensinogen I sebagai vasokonstriktor yang ringan tidak menyebabkan perubahan bermakna dalam peningkatan tekanan darah. Renin menetap dalam peredaran darah selama 30 sampai 1 jam dan terus menyebabkan pembentukan angiotensin I, setelah itu terdapat dua asam amino yang dipecah dari angiotensin I untuk membentuk angiotensin II yang dibantu oleh Angiotensin Conveting Enzym (ACE), perubahan ini hampir seluruhnya terjadi diparu-paru.

Angiotensin II merupakan vasokonstriktor yang sangat kuat yang mempunyai dua pengaruh utama yaitu untuk meningkatkan arteri. Pengaruh pertama yaitu vasokontriksi 
diberbagai organ tubuh dan timbul dengan cepat. Efek vasokonstriksi terjadi terutama pada arteriol dan jauh lebih lemah di vena. Kontriksi pada pembuluh arteriol mengakibatkan tahanan perifer total sehingga meningkatkan tekanan arteri. Pengaruh kedua adalah dengan menurunkan ekskresi air dan garam oleh ginjal, secara perlahan-lahan meningkatkan volume cairan ekstrasel, yang kemudian meningkatkan tekanan arteri selama berjam-jam dan berhari-hari berikutnya, sehingga meningkatkan tekanan pembuluh darah.

Sesuai teori yang menunjukkan bahwa pemberian estrogen sintetik secara rutin memiliki kecenderungan untuk beraktivasi terhadap angiotensin dan pemberian yang sedikit tidak memiliki kecenderungan angiotensin untuk beraktivasi. Hal ini menunjukkan bahwa status estrogen merupakan faktor yang paling penting dalam aktifitas Sistem Renin- Angiotensindan respon terhadap angiotensin II karena zat pemicu pada angiotensin bersifat responsif terhadap estrogen (Sudayasa, 2017). Metode Penelitian

Penelitian ini merupakan review dari beberapa artikel untuk mengevaluasi hubungan antara penggunaan kontrasepsi pil $\mathrm{KB}$ oral dengan kejadian hipertensi, maka pencarian dilakukan secara menyeluruh dengan mesin pencari PubMed dan Google Scholar dari tahun Januari 2010 sampai Maret 2020. Artikel yang terpilih adalah artikel yang menggunakan Bahasa Indonesia dan Bahasa Inggris. Cara pencarian dengan menggunakan kata kunci sebagai berikut: ("hypertension"[MeSH Terms]OR "hypertension"[All Fields]) AND (("mouth"[MeSH Terms] OR "mouth"[All Fields] OR "oral"[All Fields])

AND("contraception"[MeSH Terms] OR "contraception"[All Fields])) AND "side effects"[All Fields]) AND “combinaton pills" [All Fields]) Artikel yang masuk dalam kriteria inklusi adalah; 1) seseorang telah memiliki riwayat hipertensi; 2) seseorang yang menggunakan kontrasepsi oral pil KB; 3) rancangan penelitian dalam bentuk observasional dengan metode cohort, cross sectional; 4) ada kelompok pembanding; 5) ditulis dalam Bahasa Indonesia atau Bahasa Inggris. Sedangkan kriteria eksklusi dalam penelitian ini adalah; 1) artikel dalam bentuk laporan kasus dan hasil konferens; 2) wanita hamil.

\section{Hasil dan Pembahasan}

Tiga artikel yang terpilih sesuai kriteria inklusi dan eksklusi diperoleh dari berbagai jenis artikel publikasi dengan judul artikel sebagai berikut:

Pertama, Past oral contraceptive use and selfreported high blood pressure in postmenopausal women (Chiu and Lind, 2015). Kedua, Associations between oral contraceptive use and risks of hypertension and prehypertension in a crosssectional study of Korean women (Park and Kim, 2013). Ketiga, Hypertension among Oral Contraceptive Users in El Paso, Texas (White et al., 2013).

Pada artikel yang didapatkan diatas, terdapat penelitian Chiu and Lind pada tahun 2015 di Negara Australia dengan judul "Past oral contraceptive use and self-reported high blood pressure in postmenopausal women". Penelitian tersebut dilakukan karena banyak kasus yang menyatakan bahwa penggunaan kontrasepsi oral dapat meningkatkan tekanan darah. Namun dalam penelitian ini dilakukan dengan tujuan untuk mengetahui hubungan antara penggunaan kontrasepsi oral di masa lalu dan tekanan darah tinggi pada wanita pascamenopause. Metode yang digunakan dalam penelitian ini adalah metode cross dengan menggunakan instrumen kuesioner pada wanita berusia > 45 tahun hingga $\geq 67$ tahun yang dibagi menjadi beberapa kelompok dan sesuai dengan lamanya penggunaan kontrasepsi oral. Sampel yang masuk dalam kriteria inklusi sebanyak 34.289 responden dan terbagi menjadi dua golongan, golongan pertama wanita yang tidak pernah menggunakan kontrasepsi oral dan terbagi sesuai usia $<58$ tahun sebanyak 1.411 , usia 58 - 66 sebanyak 1.586 , usia $\geq$ 67 sebanyak 5.512. Golongan kedua yang pernah menggunakan kontrasepsi oral dan terbagi sesuai usia $<58$ tahun sebanyak 10.647, usia 58 - 66 sebanyak 9.213, usia $\geq 67$ sebanyak 5.920. Responden yang pernah menggunakan kontrasepsi oral dibagi sesuai lama penggunaan kontrasepsi oral. Lama pemakaian $<5$ tahun dengan usia $<58$ tahun sebanyak 2.677, usia $58-66$ sebanyak 2.930, usia $\geq 67$ sebanyak 1.817. Lama pemakaian $5-10$ tahun dengan usia $<58$ tahun sebanyak 3.903 , usia 58 - 66 sebanyak 3.636, usia $\geq 67$ sebanyak 2.169. Terakhir dengan lama pemakaian $>10$ tahun dengan usia $<58$ tahun sebanyak 4.067, usia 58 - 66 sebanyak

2.647 , usia $\geq 67$ sebanyak 1.934 . Nilai p-value dari setiap kelompok usia didapatkan dari uji statistik dan memiliki hasil diatas 0,05 yang menyatakan bahwa penggunaan kontrasepsi oral di masa lalu dan durasi penggunaan tidak terkait dengan hipertensi pada wanita pascamenopause. Wanita dengan usia $<58$ tahun yang pernah menggunakan kontrasepsi oral memiliki resiko terjadinya hipertensi sebesar 1,1 kali lebih tinggi dibandingkan dengan wanita yang tidak menggunakan kontrasepsi oral sedangkan wanita yang berusia 58-66 tahun bahkan $\geq 67$ tahun memiliki resiko terjadinya hipertensi sebesar 0,9 kali lebih rendah dibandingkan dengan wanita yang tidak menggunakan kontrasepsi oral (Chiu and Lind, 2015).

Park and Kim tahun 2013 di Negara Korea melakukan penelitian dengan judul "Associations between oral contraceptive use and risks of hypertension and prehypertension in a crosssectional study of Korean women". Penelitian ini merupakan penelitian analitik dengan rancangan cross sectional dengan sampel wanita pengguna kontrasepsi oral kombinasi (progesteron + estrogen) yang berusia 35-55 tahun. Metode pengumpulan data dilakukan oleh Korea National Health and Nutrition Examination Survey (KNHANES) atau pemeriksaan kesehatan dan gizi Nasional Korea menggunakan instrumen kuesioner yang dipilih menggunakan stratified, multistage, cluster-sampling design dengan alokasi proporsional berdasarkan National Census Registry. Setelah mendapatkan data dari setiap responden, peneliti pun melakukan skrining untuk mendapatkan sampel yang sesuai dengan penelitian sehingga didapatkan 3.356 responden. Sampel dalam penelitian terbagi menjadi dua kelompok yang pertama responden yang tidak pernah 
menggunakan kontrasepsi oral dengan jumlah 2.844 responden. Kedua yaitu responden yang menggunakan kontrasepsi oral kombinasi (progesteron + estrogen) dengan durasi yang berbeda 304 responden menggunakan kontrasepsi oral (progesteron + estrogen) $<12$ bulan, 132 responden menggunakan kontrasepsi oral (progesteron + estrogen) 12-24 bulan, 76 responden menggunakan kontrasepsi oral (progesteron + estrogen) $>24$ bulan. Pada penelitian ini digunakan uji statistik dengan menggunakan analisis perangkat lunak SAS sehingga mendapatkan nilai pvalue 0,001 yang menyatakan bahwa durasi penggunaan kontrasepsi oral (progesteron + estrogen) yang lebih lama dapat meningkatkan hipertensi. Hasil OR yang didapatkan pun berbeda dari setiap lamanya penggunaan kontrasepsi oral (progesteron + estrogen). Odd Ratio atau angka kejadian hipertensi meningkat secara signifikan dalam jangka panjang $>24$ bulan pada pengguna kontrasepsi oral (progesteron + estrogen) 1,96 kali dibandingkan dengan responden yang tidak pernah menggunakan kontrasepsi oral. Selain itu, penggunaan kontrasepsi oral (progesteron + estrogen) $>24$ bulan dikaitkan dengan resiko peningkatan prehipertensi 2,23 kali dan hipertensi atau prehipertensi 2.13 kali dibandingkan dengan responden yang tidak menggunakan kontrasepsi oral. Hal tersebut menyatakan bahwa penggunaan kontrasepsi oral dapat meningkatkan hipertensi (Park and Kim, 2013).

Penelitian dengan judul "Hypertension among Oral Contraceptive Users in El Paso, Texas" yang dilakukan di Negara Texas pada tahun 2013. Pada perbatasan ASMexico penduduk AS sering menyebrang ke wilayah Mexico untuk mendapatkan fasilitas kesehatan khususnya obat-obatan, hal tersebut disebabkan karena penduduk Mexico memiliki penghasilan yang rendah dan atau tidak diasuransikan serta penduduk AS masih kekurangan akses ke berbagai layanan kesehatan tertentu sehingga mereka menyebrang ke Mexico untuk mendapatkan fasilitas kesehatan walaupun tanpa menggunakan resep dari dokter (OTC). Pada penelitian menggunakan metode cohort/prospektif ini dilakukan pada wanita yang menggunakan kontrasepsi oral. Peneliti mengemukakan bahwa wanita yang menggunakan kontrasepsi oral pil KB oral tanpa resep dokter (OTC) akan lebih banyak mendapatkan kontraindikasi dibandingkan dengan wanita yang memperoleh pil KB oral dari klinik AS karena dapat dipastikan telah mendapatkan pemeriksaan kesehatan seperti pemeriksaan tekanan darah dan lain-lain walaupun pil $\mathrm{KB}$ oral merupakan sebuah obat golongan bebas namun memiliki efek samping salah satunya hipertensi. Tujuan dari penelitian ini adalah untuk mengetahui hubungan antara penggunaan kontrasepsi oral yang didapatkan dari klinik AS dan didapatkan tanpa resep dokter (OTC). Sampel yang didapatkan dari 2 kelompok pertama kelompok yang menggunakan pil KB oral dan didapatkan dari klinik AS (Amerika Serikat) dengan responden sebanyak 399 orang. Kedua kelompok yang menggunakan pil KB oral yang didapatkan tanpa resep dokter (OTC) sebanyak 411 responden. Pada penelitian ini digunakan uji statistik dengan menggunakan analisis chisquare dan menghasilkan nilai pvalue 0,085 sehingga menyatakan bahwa tidak ada hubungan yang signifikan antara penggunaan pil KB kombinasi yang didapatkan dari klinik AS dengan penggunaan pil KB kombinasi yang didapatkan tanpa resep dokter, namun lebih baik lagi apabila menggunakan pil KB oral dengan resep dokter di klinik dan melakukan pemeriksaan tekanan darah dan fasilitas lain agar mendapatkan hasil yang lebih baik. Nilai OR menjelaskan bahwa responden yang menggunakan pil KB kombinasi tanpa resep dokter 1,55 kali lebih besar dibandingkan yang menggunakan pil KB kombinasi klinik AS (White et al., 2013).

\section{Pembahasan}

Pada penelitian ini didapatkan 3 jenis artikel ilmiah dengan metode penelitian yang dianalisis beragam. Metode penelitian tersebut adalah cohort, dan cross sectional. Metode cross sectioal merupakan metode yang mendominasi karena terdapat 2 artikel ilmiah yang menggunakan metode tersebut dalam penelitiannya (Chiu and Lind, 2015; Park and Kim,2013). Sedangkan 1 artikel ilmiah lainnya menggunakan metode cohort (White et al., 2013).

Hasil literature review pada 3 artikel dengan tema pengunaan pil $\mathrm{KB}$ oral terhadap kejadian hipertensi memberikan beberapa informasi tentang kontrasepsi yang digunakan. Pada artikel pertama yang diteliti oleh Chiu and Lind, menjelaskan bahwa penggunaan kontrasepsi pada usia muda tidak memberi resiko terjadinya hipertensi pada saat menopause namun masih bisa juga terjadi hipertensi karena faktor lain atau confounding factor (faktor pengganggu) yang juga dapat berpengaruh terhadap kejadian hipertensi seperti faktor genetik, gaya hidup, obatobatan dan lain-lain (Ridwan, 2017). Pada artikel kedua di teliti oleh Park and Kim, menjelaskan bahwa durasi atau lama penggunaan kontrasepsi oral juga dapat mempengaruhi terjadinya hipertensi. Semakin lama waktu penggunaan kontrasepsi oral maka semakin tinggi juga resiko terjadinya hipertensi atau tekanan darah yang semakin meningkat. Pada artikel ketiga yang di tulis oleh White et al menjelaskan bahwa setiap penggunaan kontrasepsi harus dipantau atau lebih baik mendapatkan kontrasepsi yang sesuai dengan keadaan tubuh dan dari resep dokter.

Kontrasepsi oral atau pil KB yang saat ini banyak dikonsumsi oleh para wanita dapat meningkatkan resiko terjadinya hiperplasia atau peristiwa meningkatnya jumlah sel yang terjadi pada organ tententu akibat mitosis, bahkan dapat menyebabkan terjadinya karsinoma endometrium (kanker yang dimulai pada lapisan rahim) (Sujono dkk., 2013). Wanita memiliki hormon estrogen yang berfungsi mencegah kekentalan darah serta menjaga dinding pembuluh darah agar tetap normal (Rapkin, 2012). Kesimbangan hormon esterogen dan progesteron dapat dipengaruhi oleh penggunaan alat kontrasepsi hormonal atau pil KB, misalnya etinilestradiol (turunan dari hormon estrogen) yang berfungsi menghambat fertilitas. Pada penggunaan estrogen sintetis dapat menghambat sekresi Folicle Stimulatting Hormone (FSH) dan demikian pula pada penggunaan turunan progesteron sintesis misal levonogestrel yang dapat menghambat seksresi Luteinizing Hormone (LH), sehingga bila seksresi FSH dan LH 
dihambat maka akan terjadi ketidakseimbangan hormonestrogen dan progesteron dalam tubuh. Hal tersebut dapat merusak sel endotel yang memicu plak di pembuluh darah sehingga tejadi tekanan darah yang tinggi. (Sujono, Milawati and Hakim, 2013).

Penyebab gejala timbulnya tekanan darah tinggi adalah pengaruh hormon estrogen dan progesteron terhadap Renin Angiotensin Aldosteron System (RAAS). Apabila RAAS teraktivasi, maka kecepatan aldosteron akan meningkat. Aldosteron ini nantinya dapat membuat ginjal lebih banyak menyaring air, elektrolit serta garam di dalam darah. Hal ini menyebabkan jumlah cairan dan elektrolit bertambah, sehingga tekanan darah pun meningkat (Guyton, 2012). Hormon estrogen dan progesteron dalam pil KB menyebabkan tekanan darah tinggi sehingga mekanisme feedback (umpan balik) akan bekerja sehingga Renin Angiotensin Aldosteron System (RAAS) dalam tubuh akan terganggu (Gaby, dkk 2012). Apabila volume tekanan darah di glomeruli ginjal menurun akibat penyempitan arteri, maka ginjal dapat membentuk dan melepaskan enzim proteolitis renin. Dalam plasma renin akan menghidrolisa protein angiotensinogen (yang terbentuk didalam hati) menjadi angiotensin I. Zat ini dapat diubah oleh enzim Angeotensin Converting Enzyme (ACE), yang disintesa di paru-paru dan menjadi zat aktif angiotensin II.

Angiotensin II juga memiliki peranan kunci dalam menaikkan tekanan darah melalui dua aksi. Aksi pertama adalah meningkatkan sekresi hormon antidiuretik (ADH) dan rasa haus. ADH diproduksi di hipotalamus (kelenjar pituitari) dan bekerja pada ginjal untuk mengatur osmolalitas dan volume urin. Dengan meningkatnya ADH, sangat sedikit urin yang diekskresikan ke luar tubuh (antidiuresis), sehingga menjadi pekat dan tinggi osmolalitasnya. Untuk mengencerkannya, volume cairan ekstraseluler akan ditingkatkan dengan cara menarik cairan dari bagian intraseluler. Akibatnya, volume darah meningkat yang pada akhirnya akan meningkatkan tekanan darah. Aksi kedua adalah menstimulasi sekresi aldosteron dari korteks adrenal. Aldosteron merupakan hormon steroid yang memiliki peranan penting pada ginjal. Untuk mengatur volume cairan ekstraseluler, aldosteron akan mengurangi ekskresi $\mathrm{NaCl}$ (garam) dengan cara mereabsorpsinya dari tubulus ginjal. Naiknya konsentrasi $\mathrm{NaCl}$ akan diencerkan kembali dengan cara meningkatkan volume cairan ekstraseluler yang pada gilirannya akan meningkatkan volume dan tekanan darah (Nuraini, 2015). Terdapat keterbatasan dalam menyusun literatur revisi ini, salah satunya adalah tidak terdapat meta analisis atau suatu teknik statistika untuk menggabungkan 2 atau lebih hasil penelitian sejenis sehingga dapat diperoleh paduan data secara kuantitatif. Meta analisis lebih banyak digunakan untuk uji klinis karena uji klinis desainnya lebih baku dan memberikan bukti hubungan kausal yang paling kuat dan lebih akurat.

\section{Kesimpulan dan Saran Berikut}

merupakan kesimpulan dari penelitian ini: a. Penggunaan kontrasepsi pil $\mathrm{KB}$ oral dapat menimbulkan resiko hipertensi

b. Penggunaan kontrasepsi oral di masa lalu dan durasi penggunaan tidak terkait

c. Durasi atau lama penggunaan kontrasepsi dengan hipertensi pada wanita pascamenopause oral juga dapat mempengaruhi terjadinya hipertensi. Semakin lama waktu penggunaan kontrasepsi oral maka semakin tinggi juga resiko terjadinya hipertensi atau tekanan darah yang semakin meningkat.

d. Setiap penggunaan kontrasepsi harus dipantau atau lebih baik mendapatkan kontrasepsi yang sesuai dengan keadaan tubuh dan dari resep dokter Berikut merupakan saran dari penelitian ini:

a. Pada penelitian selanjutnya diharapkan untuk melakukan pemantauan efek samping dari alat kontrasepsi yang digunakan agar tidak terjadi resiko yang tidak diinginkan.

b. Penelitian selanjutnya disarankan untuk membuat data meta analisis atau forest plot agar hasil yang didapat lebih akurat.

\section{Daftar Pustaka}

BKKBN (2012) 'Keluarga Berencana', Data Statistik Indonesia.Chiu, C. L. and Lind, J. M. (2015) 'Past oral contraceptive use and selfreported high blood pressure in postmenopausal women Disease epidemiology- Chronic', BMC Public Health, 15(1), pp. 1-6. doi: 10.1186/s12889015-1392-3.

DinKes (2017) 'Profil Kesehatan Kota Malang 2017', Journal of Chemical Information and Modeling,pp.16891699. doi:10.1017/CBO9781107415324.004.

Farida, F. (2017) 'Penggunaan Alat Kontrasepsi Suntik Dan Pil terhadap Peningkatan Berat Badan Pada Ibu Pasangan Usia Subur', Strada Jurnal Ilmiah Kesehatan, 6(2), pp.4347. doi:10.30994/sjik.v6i2.1.

Gaby (2012) 'Analisis Hubungan Penggunaan pil KB dengan Kejadian Hipertensi pada WUS di Kecamatan Tombariri'.

Guyton, A. C. (2012) Buku Ajar Fisiologi Kedokteran. Jakarta.

Handayani, S. D. (2010) Buku Ajar Pelayanan Keluarga Berencana. Yogyakarta: Pustaka Rihama.

Kuito, D. (2019) 'Konsensus Penatalaksanaan Hipertensi 2019', p. 118.

Kurniawati, H. (2010) 'Hubungan Pemakaian Kontrasepsi Pil Kb Kombinasi Dengan Tekanan Darah Tinggi Pada Wanita Pasangan Usia Subur Di Puskesmas Kecamatan Grogol Petamburan Kota Administrasi Jakarta Barat Tahun $2010^{\prime}$. 
Nuraini, B. (2015) 'Risk Factors of Hypertension', J Majority, 4(5), pp. 10-19.

Park, H. and Kim, K. (2013) 'Associations between oral contraceptive use and risks of hypertension and prehypertension in a cross- sectional study of Korean women. BMC Women's Health; http://www.biomedcentral.c om/1472- 6874/13/39', BMC Women's Health, 13(39), pp.1-7.

Parmin (2014) 'Penerapan Critical Review Articel Pembelajaran IPA Untuk Meningkatkan Kemampuan Mahasiswa Dalam Menyusun Proposal Skripsi', 4.

Rapkin, A. (2012) 'Pathophysiology of Premenstrual Syndrome and Premenstrual

DysphoricDisorder',Menopause International Journal.

Ridwan, M. (2017) Mengenal, Mencegah \& Mengatasi Silent Killer Hipertensi. Edited by S. Ika. Yogyakarta: Romawi

Press.

Setiawati, E., Handayani, O. W. K. And Kuswardinah, A. (2017) 'Pemilihan Kontrasepsi Berdasarkan Efek Samping Pada Dua Kelompok Usia Reproduksi', Unnes Journal of Public Health, 6(3),p.167. doi:10.15294/ujph.v6i3.11543.

Sudayasa, I. P. dkk (2017) 'Hubungan lama pemakaian kontrasepsi oral dengan hipertensi', (April), pp. 46-50.

Sujono, T. A., Milawati, A. and Hakim, A. R. (2013) 'Pengaruh Pemakaian Kontrasepsi terhadap Peningkatan Tekanan Darah Wanita di Puskesmas Wonogiri Effect of Contraceptive Agents to Women Blood Pressure in Wonogiri Community Health Centers', Jurnal Farmasi Klinik Indonesia, 2(2), pp. 61-70.

Susanti, L. et al. (2018) 'Pengaruh Kontrasepsi Hormonal Hormonal Contraception Effect', Collaborative Medical Journal (CMJ) Vol 1 No 3, 1(3), pp. 1-9.

Sylvestris, A. (2014) 'Hipertensi dan Retinopati Hipertensi', 10.10 No.1.

White, K. et al. (2013) 'Hypertension among oral contraceptive users in El Paso, Texas', Journal of Health Care for the Poor and Underserved, 24(4), pp. 1511-1521. doi: 10.1353/hpu.2013.0172. 